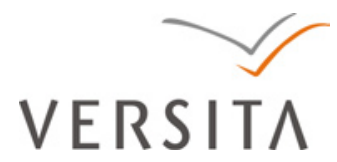

Folia Oeconomica Stetinensia

DOI: 10.2478/foli-2013-0009

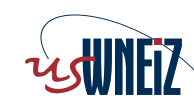

Wydzial Nauk Ekonomicznych i Zarządzania

Uniwersytetu Szczecińskiego

\title{
THE PRICE BUBBLE MORPHOLOGY
}

\author{
Prof. Waldemar Tyc \\ Wroctaw University of Economics \\ Faculty of Economics, Management and Tourism \\ Komandorska 118/120, 53-345 Wrocław, Poland \\ e-mail: waldemart@onet.eu
}

Received 22 August 2013, Accepted 18 November 2013

\begin{abstract}
The article presents a discourse on the mechanism by which price bubbles emerge and burst. For idealization purposes the author assumes that even though price bubbles emerge in various markets, their morphology differs from market to market, be it the hi-tech stock (or, more generally, the stock market), the real estate market (where land is of fixed supply) or the housing market. The sources of their diversification lie in the type and weight of the causes of their appearance, the differences between their causative and functional determinants and the market feedbacks. Any interpretation of the nomological diversification of price bubbles (in the sense of their categorisation) requires looking at the system pragmatics and the market in which they emerge. Thus the designations of economic systems and the specifics of markets constitute both the economic and the institutional environment of their origin. They also constitute the necessary context for their understanding and interpretation, as price bubbles rise and collapse within specific functional structures of an economic system.
\end{abstract}

Keywords: price bubbles, idealization models, soft/hard financing, asymmetry of information, moral hazard, causative determination, functional determination, functional structure, side effects of human actions, deductive-nomological (DN) model.

JEL classification: D53, D81, D82, G17. 


\section{Introduction}

The subject of this article is nomological diversification of price bubbles. This refers to the causative and functional determinants of their origin and burst, even though price bubbles sometimes also differ in their lifetime, structure of financing as well as in their micro and macroeconomic impact. The problem is of epistemological nature. At first sight, price bubbles seem all alike nomologically, in the sense that they are subject to the universal laws of economy. But is that really so? Can they be fully explained by means of the laws of supply and demand? Even if those laws are of objective (stochastic) nature, they were formulated in the context of rigid, explicit premises of the neoclassical theory of economics. The theory of supply and demand is based on an implicit assumption of hard financing of the expenditures on the procurement and production of goods and services. This means a close correlation between the income and expenditure, both in consumption and production (investment).

The author attempts to compare the morphology of price bubbles emerging in various markets, those of the hi-tech stock (or, more generally, the stock market), the real estate market (where resources are of fixed supply) or the housing market.

The origin of price bubbles is considered as determined by a number of economic, institutional and psychological factors. This opinion can hardly be opposed, given the fact that their appearance is always determined by a number of factors and, what is more, results from a synergy of various behaviours. It should be noted that the activities of individual market actors, driven by rational motives and logical thinking, may bring a totally unintended, unanticipated and frequently undesirable results which may even be harmful to the community. The understanding and interpretation of the price bubble morphology must then involve identification of the synergic effect of individual actions ${ }^{1}$.

In the ontological sense, the common feature of all price bubbles is their foundation in the speculative activities arising from human greed. Therefore the price bubbles are frequently referred to as speculative bubbles ${ }^{2}$. However, interpreting price bubbles with the assumption that they always arise from speculation and greed is fallible, as that would mean the need to use empathy towards investors, i.e. understanding and defining their intentions ${ }^{3}$. The speculative nature of any human activity can be identified only on the ex post basis, while ex ante we are incapable of distinguishing the speculative and non-speculative purchases (e.g. of housing), or the purchases arising solely from avarice or from the need to meet an existential necessity. While it is true that the investment decisions of small individual investors are not enough to 
create a price bubble, the market functions differently from democracy and the rational actions of a large speculative investor may play a crucial role in its emergence.

Charles Kindleberger defines a price bubble as a sharp rise in price of an asset or a range of assets in a continuous process, with the initial rise generating expectations of further rises and attracting new buyers interested in profits from trading in the asset. On the other hand, Peter Garber interprets a price bubble as an amplitude of asset price changes that is impossible to explain with the factors fundamental to the asset category in question. He also emphasizes that we can speak about a price bubble when a rapid rise of an asset price far beyond its "fundamental value"4 ends with an equally rapid price correction (burst) ${ }^{5}$.

Those definitions lead to two important observations. Charles Kindleberger emphasizes the significance of expectations in the context of an upward trend - the rising prices of specific assets make the expectation of further growth legitimate. On the other hand, Peter Garber points out the existence of factors fundamental to a "specific category of assets", thus implying the existence of different categories of price bubbles.

Here we should stop and ask if it is possible at all to understand price bubbles without categorizing them. The answer is positive if we reduce the causes of their emergence to a single category of purely economic motives driving the investors and speculators. Their objective is always the same - earning as high as possible (maximum) return on investment whether the investment is in stock, housing, land, standardized goods, or in-kind investment in fixed tangibles.

The rate of return on investment defines the returns earned per unit of capital invested and is expressed in relative terms. Its calculation formula is:

$$
r=\frac{(d+\Delta V)}{V}
$$

where:

$r \quad$ - return on investment,

$V$ - initial net market value of a specific asset,

$\Delta \mathrm{V}$ - change in the net market value of the same asset.

A key factor for any investment decision is the anticipated return on investment estimated ex ante, i.e. before the investment decision is taken. Its real value remains uncertain at the moment of decision taking, since there is no certainty about the future. However, the very name 
of anticipated return on investment suggests the value of returns to be expected after a specified time. In other words, this represents a hypothetical rate of return on a specific investment ${ }^{6}$.

Thus the anticipated return on investment becomes a key driver of investment decisions which, however, does not operate in a void. It also requires comparison with the cost of capital invested, expressed as the market interest rate $(\mathrm{k})$, or the opportunity cost. Thus for the purpose of idealization it can be assumed that the argument for investing in specific assets will be a positive difference between the return on capital (r) and the cost of capital (k), i.e.

$$
r-k>0
$$

This means that the investor will earn a surplus of returns on each unit of capital invested over the cost of this capital. This is, ceteris paribus, a sufficient condition of various investments. The objective of any investor (or speculator) is earning a maximum surplus between the anticipated return on investment and the cost of capital - hence the migration of capital between its various applications in search of as high profitability as possible.

This seems to allow the conclusion that price bubbles will emerge in the market segments or on the assets promising the highest return on investment of all the opportunities on offer. Even if heuristically fruitful, this statement remains insufficient for the explanation of differences in the origin of price bubbles on different assets as in this case a simple cause-effect explanation would constitute monocausality. Consequently, any interpretation of the nomological diversification of price bubbles requires looking at the system pragmatics and the market in which they emerge. The designations of economic systems and the specifics of markets constitute the economic and institutional environment of their origin and the context necessary to understand and interpret them. More precisely, price bubbles rise and collapse within specific functional structures of an economic system.

To make the explanation clearer, let's look at the three basic idealized models of price bubbles, emerging in the markets for stock, land and housing. On the stock market and the housing market we deal with the assets that are of similar categories - both types are produced, in the economic sense of the word. This means that their supply is elastic - we can always produce more of them. On the other hand, land is a natural resource and additionally its supply is fixed. 


\section{The hi-tech price bubble}

Price bubbles at new-technology stock market have their economic and psychological determiners. They emerge from the optimistic outlook for appreciation of the "novel, creative concept" stocks, which usually sell the expectations for future profits or, as Stephen F. LeRoy and Christian Gilles put it, are "blown up by the air of great words" . This also means that the most significant factors in price bubble appearance are economic and behavioural designations, even though they are functionally determined by material and institutional constraints.

Nouriel Roubini states that price bubbles are the more treacherous that every one of them has its plausible story which makes people believe that a new era is at hand. This statement is a perfect commentary to the worldwide stock exchange boom caused by the optimistic outlooks for the IT industry. The 1995-2001 period saw billion-dollar investments in stocks that later on proved overpriced and overinvested. The investors keen for stock exchange profits found new investment areas in the "new economy" stocks which were regularly appreciated even though most of them never showed any significant profits. The popular belief that "dot-coms will never go bust" led to some irrational decisions. The dot-com boom was fuelled by the large investment funds who kept investing both in the stocks and in the new ventures of the IT industry. This was done on the "crowd madness" principle and the decisive factor for investments was the willingness to outrun the crowd. The dot-com boom was similar to the previous booms, related to popularization of railway, automobiles, radio, TV or personal computers. The market showed interest in companies whose operations were related to a particular technological innovation. Particular importance was attributed to innovations in IT and telecommunications.

The popular belief in the success of innovation-oriented investments was grounded in the popular opinion that new IT technologies are not only pushing the old ones out of the market but also establishing a new era for humanity and will change the human life forever. The establishment of new dot-coms and their IPOs were supported by venture capital who saw innovation as the prime source of future profits. The role of such innovative ventures was to be assumed by the products and technologies of the new economy.

The US-based dot-coms, a majority of whom were quoted at NASDAQ (National Association of Securities Dealers Automated Quotations), reached very high prices in the early 2000. As a result, the total capitalization (stock price multiplied by the total volume) of the well-known online bookseller Amazon.com exceeded the total market value of all the publishers listed at NYSE. Overall capitalization of Priceline.com, an online travel agency operating as an 
auctioneer of still unsold air tickets, was greater than that of the largest US airlines - United, Delta or American Airlines ${ }^{8}$.

The differences in stock pricing presented in Table 1 illustrate the hypothetical loss per unit that could be (or was) suffered by the investors who bought the stock at bull market and sold only after the price bubble burst.

The shopping frenzy for the 'new economy' stock subsided in the early 2000. The NASDAQ Composite index peaked on $10^{\text {th }}$ March 2000, reaching 5048.62 at day closure (his intra-day peak was 5132.52). Then a rapid breakdown occurred. The index plunged to 2000 . Investors responded with funds withdrawal and selling out. The consequence was a downturn in dot-com stock. The quotations started plummeting and the subsequent panic at the global markets affected valuation of non-IT stock as well.

Helplessness (trouble) in assessing the hypothetical value of new-technology stocks usually makes investors overestimate the possible future returns from such investments. This is why they expect stock appreciations to continue. During a boom for a particular type of stock, the investors sometimes even do not care to have a good look at the companies they invest in. But we should remember the words of Warren Buffet who declared that he won't invest in companies whose business he does not understand 9 .

Table 1. Fluctuations in the leading "new economy" stock prices at US markets (2000-2002)

\begin{tabular}{|l|l|r|r|c|}
\cline { 2 - 5 } \multicolumn{1}{c|}{} & \multicolumn{1}{|c|}{ Business type } & $\begin{array}{c}\text { Peak price } \\
\text { in 2000 }\end{array}$ & $\begin{array}{c}\text { Bottom price } \\
\text { in 2001-2002 }\end{array}$ & Difference \\
\cline { 2 - 5 } & \multicolumn{2}{|c|}{$\$$} \\
\hline Corning & $\begin{array}{l}\text { Supplier of optical fibre and hardware } \\
\text { for IT \& telecoms }\end{array}$ & 113.33 & 1.30 & 112.03 \\
\hline JDS Uniphase & Communication infrastructure supplier & 297.34 & 1.64 & 295.70 \\
\hline Lucent Technologies & Telecommunication solutions supplier & 79.93 & 0.71 & 79.22 \\
\hline Nortel Networks & ICT solutions supplier & 143.62 & 0.45 & 143.17 \\
\hline Princeline.com & Online travel agency & 165.00 & 1.37 & 163.63 \\
\hline Yahoo.com & Online media company & 238.00 & 8.45 & 229.55 \\
\hline Amazon.com & E-commerce company & 75.25 & 5.51 & 69.74 \\
\hline
\end{tabular}

Source: own work, based on: Malkiel (2003), p. 64.

The situation with dot-coms was that stock supply elasticity was smaller than the demand elasticity. This was so because the growing prices encouraged new stock issues (and new investments in this sector) but failed to discourage demand - instead, the number of willing investors kept increasing. As a result, the influx of investment capital outpaced the supply of stock so much that the sector got into excessive financial liquidity. Thus the negatively oriented 
demand curve (D) turned into the positively oriented demand curve $\left(\mathrm{D}_{1}\right)$ which created conditions for building over-liquidity of the dot-com market (cf. Figure 1).

Some investors, acting on purely speculative motives, purchased stock believing that they will manage to sell it at a higher price to a greater "fool" in the future and hoping that they will not become the last 'fool' in the chain to offer the highest bid. Others believed that if stock was currently appreciated, it will remain so in the future. Consequently, more and more investors went shopping and thus pushed the prices up. Their exuberance prevailed over a rational and reliable valuation of the stock, and in their choices the buyers used the technical analysis of price fluctuations rather than the fundamental analysis of the companies whose stock they were buying.

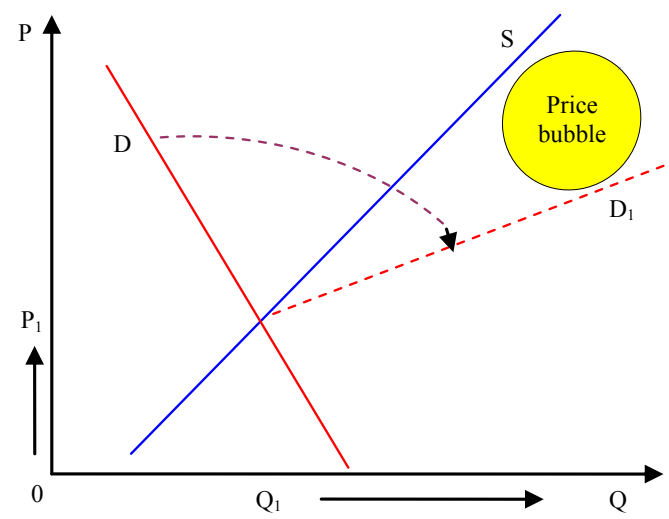

Fig. 1. The hi-tech price bubble mechanism

Source: own research.

Both private and institutional investors followed the trend (imitative behaviour). For institutional investors it was indeed necessary to participate in the price bubble as the market segment was providing the highest rate of return. Moreover, there was always the risk that other portfolio managers had some information which they had failed to obtain, so following others might prove beneficial. In sociology, this phenomenon is referred to as "pluralistic ignorance".

After a time, exuberance started to prevail over rational and reliable stock valuation. Finally, however, most investors got aware that such a high valuation has no fundamental basis. They started to sell out, pumping money out of the market, and the growing supply of the stock had to cause drastic reductions in valuation. This meant a pop of the dot-com price bubble. 
The demand curve $\left(\mathrm{D}_{1}\right)$ did not change its former positive orientation, which meant parallel changes in pricing and demand. In this way the falling prices triggered (enforced) sale of the stock held (cf. Figure 2). The growing supply also resulted in lower prices and this added to the panicked sell-out. The ultimate result was a reverse bubble, in which various stock became underpriced.

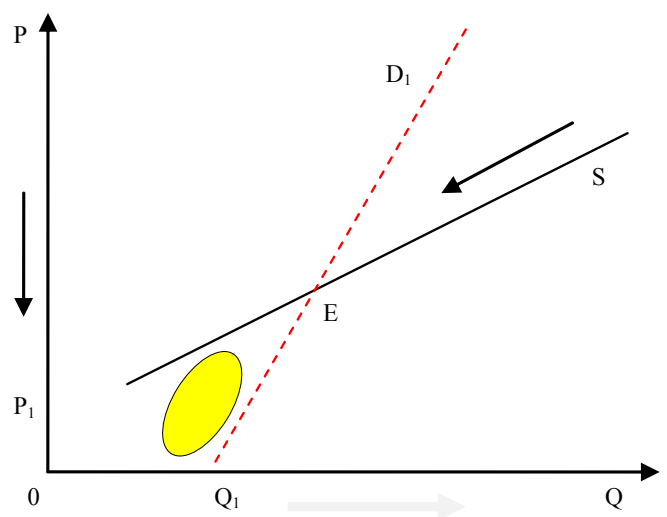

Fig. 2. The mechanism of a dot-com bubble pop and a shift to reverse bubble Source: own research.

Burst of the dot-com price bubble was determined psychologically, but its functional determinants were of economic and institutional nature as the downturn in prices enforced the sale of assets. The sale got necessary to maintain the capacity for servicing the debt incurred to finance their original purchase, the more so that new credits got hardly available.

\section{The land price bubble}

The land price bubbles are determined materially. They are grounded in the asset scarcity and founded on the activities aimed at meeting the demand in the situation of a rigid or hardly elastic supply. This means that the main determinant of such a price bubble occurrence are material and economic constraints, which in turn are conditioned by institutional and psychological factors.

During the 1980s, the Japanese statistics of land value demonstrated that the value of land built in with the Tokyo Imperial Palace was the same as the total area of California, the Chiyoda district of Tokyo was equivalent in price to the whole territory of Canada and the value of the entire Japanese territory was $60 \%$ of the rest of the world in terms of land prices ${ }^{10}$. 
In the late 1980s the Nikkei index tripled in value, and the average prices of land in the largest cities of Japan nearly quadrupled. The practice of granting loans secured against land to finance stock investments became common. During that tome, Japanese banks did not apply any credit-worthiness scoring in their loan granting procedures. Customer's credit-worthiness was less important than trust. This was the effect of the loose monetary policy of the Japanese central bank and similar credit policies of the commercial banks, which added up to the soft financing of investments.

However, in 1989 a common Japanese could no longer afford buying land as the prices got sky-high. The Japanese government decided to tighten up the financial policies. In the late 1989 the interest rates were raised. There was an informal ban on accepting land as the collateral of credits granted by the commercial banks. Those measures resulted in a crisis at the markets for land, real estate and stock exchange. During the following two years the Nikkei index tripled down, while land prices got four times lower within six years. The impact was soon felt in the banking sector performance and this brought the entire economy to a standstill. The consumption demand was significantly down and deflation appeared in Japan to stay for the long years to come ${ }^{11}$.

The rapid appreciation of land in Japan translated into problems for Japanese banks. They used to grant high credits collateralized with the highly-valued land to Japanese corporations. However, when the corporate debtors got in financial trouble, banks were left with nonperforming credits as the debtors were unable to raise enough money from land sale to pay the credits back.

Banks were definitely not alone - the same problem was faced by small investors and investment funds, for whom land had been the best option for capital allocation during the period of land appreciation coupled with low interest rates and high money supply. And they would be hardly to blame, since in the situation of the land appreciation rate being a multiple of the interest rates offered on savings, those investment decisions were economically sound, even if they ultimately brought about the emergence of a price bubble. The situation clearly displays the paradox of rational behaviour. The investors consider land as a vehicle of capital investment, which means their readiness to sell at higher prices. In line with the principle of market equilibrium, the sale will occur when the asset appreciation rate becomes equal to the interest rate. As long as the appreciation rate remains higher, it is an incentive for investment. At the same time this means that low interest rates constitute an incentive to invest in fixedsupply resources. 
The supply of the natural factors of production, especially the non-renewable ones (including land) is naturally limited. Therefore no change in price will change the fixed supply because the available volume is fixed. There is an increase in both the population and the population's income. As this increase progresses, the limited (fixed) supply of land reduces the proportion of the land resources available to the number of potential buyers. Hence the drive for investment in land with the prospect of resale later on.

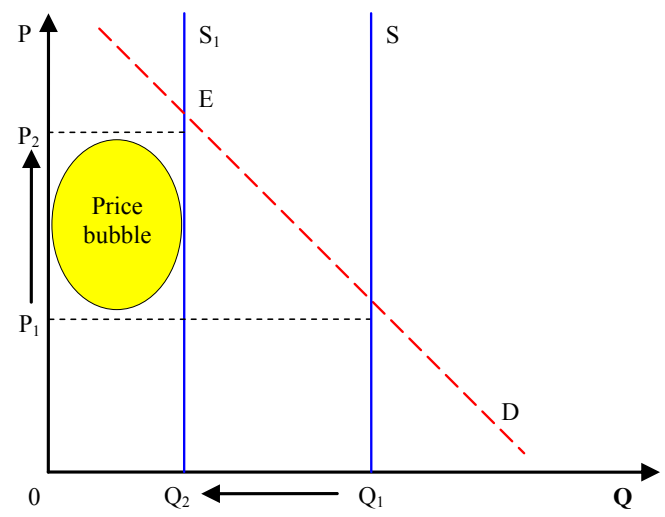

Fig. 3. The supply-driven land price bubble mechanism

Source: own research.

The course of the supply curve (S) from the coordinate origin point depends on the initial volume of land available and its historical use. This means that with the growing demand for land, the limited supply will cause its appreciation (cf. Figure 3). This also means that there is a temptation of speculative purchases to artificially decrease the supply still further and thus enhance the appreciation. A good example here is the speculative buy-out of land in the Canaries, in southern France and Spain, or in Japan of the 1980s.

Those investments were financed on the one hand from the relatively large savings with low interest rates offered and on the other from the relatively cheap and easily available credits. The price bubble was additionally blown with the anticipations for further appreciation that translated into high demand (cf. Figure 4).

The land price bubble pop is determined:

- with supply-driven bubbles - by material determinants, functionally conditioned by economic and institutional constraints,

- with demand-driven bubbles - by economic determinants, functionally conditioned by material, institutional and psychological constraints. 


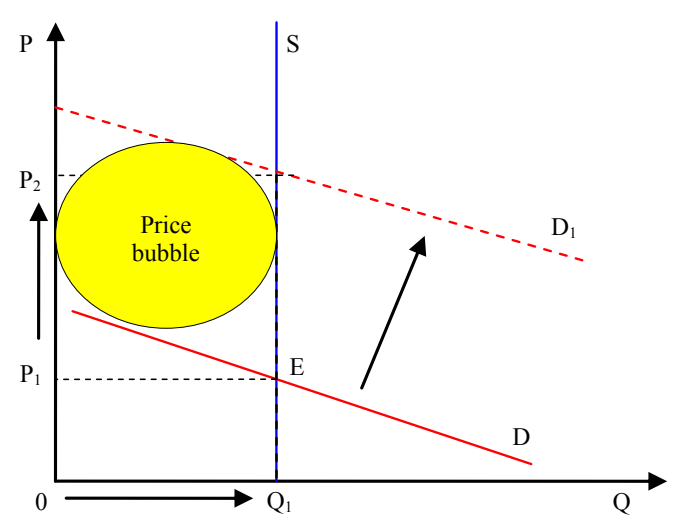

Fig. 4. The demand-driven land price bubble mechanism

Source: own research.

With the supply-driven bubbles, i.e. those arising from the diminishing availability of fixed-supply assets, for idealization purposes it may be assumed that the burst will be triggered by zero availability. However, this is an over-idealization and over-simplification, firstly because it refers to the primary market and secondly because it implies that the market remains static. Therefore an attempt to explain a price bubble pop with the material constraints on the supply side seems monocausal and heuristically fruitless. We cannot forget that the market is a dynamic mechanism of information distribution and trade exchange and thus for land transactions we must assume that even when the primary buy-out is complete, the secondary market will keep operating. This is so because even though land is a fixed-supply asset, in the physical sense it does not disappear and any transaction will affect its ownership title only. Additionally, land development may increase its valuation. The same refers to changes in the institutional constraints of its use (e.g. re-classification of land from agricultural to housing, or the introduction of a zoning plan). Thus the market offer of one and the same land may undergo changes driven by its institutional or technical status.

It is far more fruitful for an explanation of land bubble bursts to assume that price bubbles are demand-driven. Such an approach not only allows grasping the regularities in land investment decisions but also accounts for the feedbacks occurring in the market. 


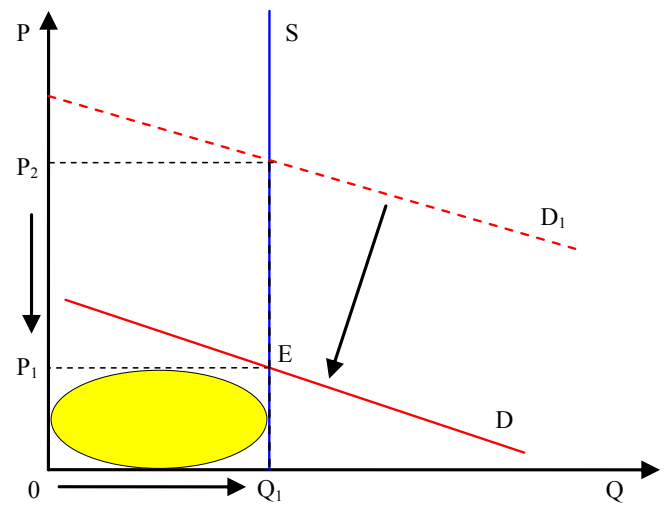

Fig. 5. The mechanism of a land price bubble pop and a shift to reverse bubble Source: own research

Bursts of demand-driven bubbles are determined economically and functionally conditioned by material, institutional and psychological constraints. The most significant economic determinant is the interest rate that defines the cost of capital in the process of selecting the best investment options. Therefore an increase in interest rates may cause capital withdrawal from the market in search of a higher rate of return. Additionally, the impulse of interest rate rise will give rise to market feedback as the increased cost of credit will take the land investment profitability down. This in turn will cause problems with servicing the existing debt (create bad debts), resulting in a further increase in interest rates and thus provide an argument for a faster withdrawal of capital from the land market. This process will coincide with poorer outlook for land valuation and the related migration of capital for optional applications.

Ultimately, the vanishing demand for land (a fixed-supply asset) will bring about its depreciation and a rise of reverse bubble (cf. Figure 5). The situation will reverse when the anticipated annual appreciation of land will go down at least to meet the interest rates.

\section{The housing price bubble}

The housing market bubbles are determined economically, i.e. they are mainly blown up by the economic and institutional factors even though functionally they are conditioned by the material and psychological constraints.

Housing is an asset belonging to the staple class and as such can be treated either as a consumer staple or a capital investment. Social policies aimed at supporting families in 
meeting their housing needs generally focus on the demand side through subsidizing mortgages or through introducing preferential interest rates on housing credits. Cheap housing credit additionally brings the cost of housing construction down, which translates both into increased supply and into increased profitability of the construction industry.

Generally, housing price bubbles are driven by two major factors: availability of soft financing, which may give rise to moral hazards, as well as the anticipated appreciation. According to Herring and Wachter, a rise in the housing (real estate) prices encourages banks to enhance their lending capacity for this market for at least two reasons ${ }^{12}$.

- When an asset held by a bank as a credit collateral gets appreciated, the bank capital increases. Therefore the bank is interested and willing to offer more credits and loans to the real estate sector.

- When the market value of (real estate) collaterals held in relation to the already granted credits and loans goes up, the lending risks go down and the capacity for financing real estate grows without rising the probability of bank insolvency.

On the other hand, Green and Wachter claimed that if expectations about future house prices are based on observed ex post home price changes, bubbles can emerge ${ }^{13}$. A typical example of housing bubble occurred in the US during 1999-2006: as the home valuations was departing from the home construction index, the real estate market saw appreciation. There, a decisive factor was the monetary policy, which with its low interest rates, lenient supervision and product innovations on the credit side supplied the real estate market with extra liquidity.

Figure 6 illustrates the mechanism of housing price bubble. Point $E$ is the market equilibrium point, defined as the meeting point of the negatively oriented demand curve (D) and the positively oriented supply curve (S).

The housing prices and availability are determined at the housing market, where demand is typically more elastic than supply. This means that the percentage change in valuation would bring a stronger change in demand than in supply. With low interest rates, investing in real estate looks more profitable and as a result housing prices start to climb. The supply elasticity gets increased, which in Figure 6 is represented as a non-parallel shift of the supply curve (S) to $\left(\mathrm{S}_{1}\right)$. This is so because housing is a man-made asset and as such its supply can respond to the growing demand. At the same time, the low interest rates discourage savings and encourage taking mortgages.

Banks and credit companies are interested in increasing their landing capacity. Credit availability provides an opportunity to earn profits through leverage. This means people start investing in "second" or even "third" homes. This shifts consumption financing from savings 
to asset appreciation. At the same time this means that households spend more than they earn, i.e. start having negative savings, and finance their consumption with credits collateralised with the part of assets that has not been offered as a collateral before. This works as long as the rate of real estate appreciation rate is higher than the rise in the cost of leverage financing (including the interest payable).

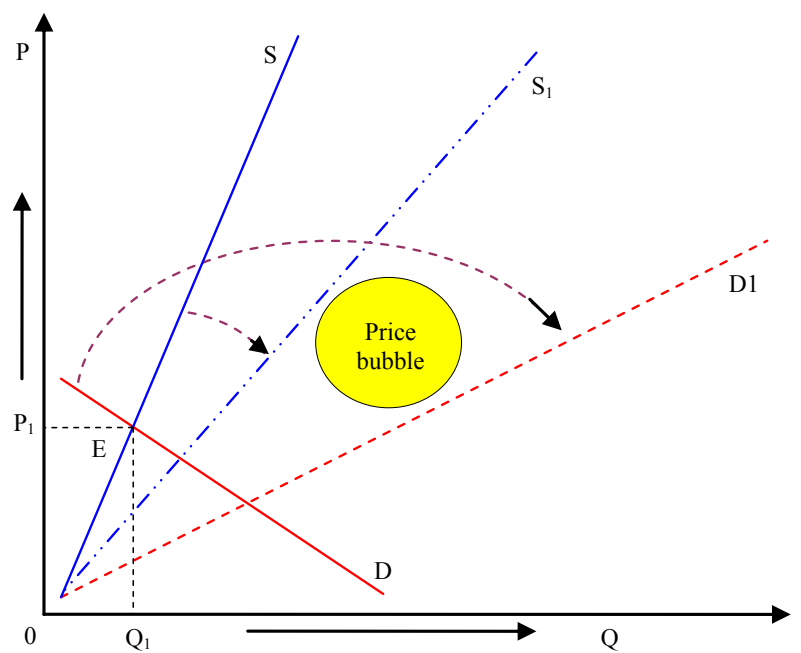

Fig. 6. The housing bubble mechanism

Source: own research.

The continuing rise in housing valuation makes the demand rise instead of falling and the demand curve gets positively oriented. The demand curve transformation from (D) to $\left(\mathrm{D}_{1}\right)$ is presented in Figure 6. The departure of the supply curve $\left(S_{1}\right)$ from the demand curve $\left(D_{1}\right)$ is a symptom of a price bubble, depicted as the yellow circle between them.

However, this disparity between home valuation and home construction index cannot last forever. Excessive liquidity of this market sector has its limitations, set by the capacity of repaying the credits and loans taken to finance the construction. If such capacity is exhausted and bad debts start accumulating, the natural result is a rise in interest rates and credit-related charges as well as stricter criteria of credit worthiness. This triggers a market feedback, since shortages of capital to finance housing purchases result in decreased demand which in turn brings the prices down. The depreciation reduces the value of credit collaterals held by the lending institutions who become less willing to finance housing which now carries an increased credit risk. 


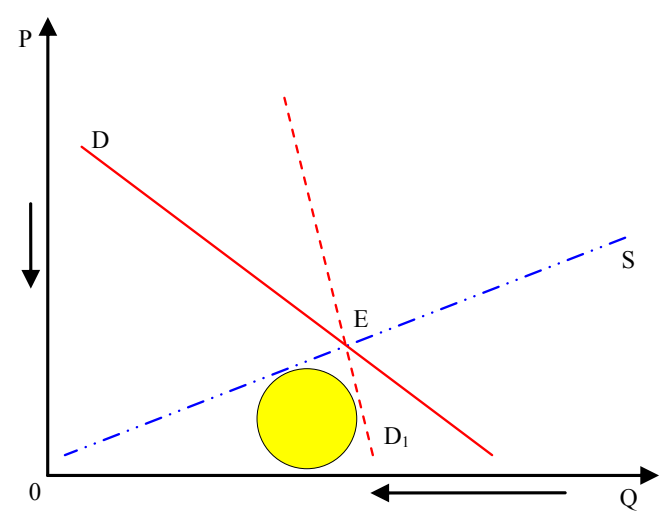

Fig. 7. The mechanism of a real estate bubble pop and a shift to reverse bubble Source: own research.

Even though price bubbles (especially the US ones) managed to diversify risks through collateralisation of the earlier credits, the rate of accumulating bad debts was more than proportional to the number of performing credits. In their willingness to recover the credits granted, banks embarked on collection procedures, with house repossession and sale seen as the only way of funds recovery where the house was the only credit security. Consequently, market received a large supply of housing and could respond only by further depreciation, which brought the solvency of those who had invested in real estate for speculation purposes to a still lower level.

In Figure 7 the demand curve $\left(D_{1}\right)$ is already negatively oriented - please note that in Figure 6 its orientation was positive. This change means that the change in prices (depreciation) should enhance demand for housing. However, this does not happen as the demand is hardly elastic. Therefore, despite the fall in housing prices the demand cannot respond adequately. Conversely, the housing supply is elastic - housing appreciation results in an increased supply while depreciation shrinks its volume. Unfortunately, the shortage of capital to finance house purchases forced both the owners and the repossessing banks to sell at prices so low that the developers couldn't even recover the cost of construction. For many developers this meant bankruptcy or winding up. After the bubble burst, the housing market regained its equilibrium at a supply level similar to that seen during the period of excessive financial liquidity, but at a far lower price level. 


\section{Conclusions}

In the hereby article the mechanism of price bubbles has been discussed. It has assumed that the recognition and explanation of price bubbles morphology must be based on the synergic effects of individual behaviours. The sources of price bubbles have been reduced to four main groups of factors originating in the human choice limitations, i.e. material and economic constraints as well as institutional and psychological limitations. It has also been recognized that the descriptive model of price bubbles explanation is no longer useful in the essential sense, as it does not show the core of the problem. That brings back the necessity of understanding price bubble diversity and identifying the factors of constitutive and regulative nature as well as defining the nature of their interaction (feedback). It has also been assumed that understanding of the nomological differences among the price bubbles requires discarding the basic assumptions of the orthodox economics theory. Although price bubbles occur on many markets, their morphology differs. One can easily observe the differences between price bubbles in hi-tech stock (or the stock market in the wider sense), price bubbles of the land market (fixed supply resources) and finally the price bubbles on the real estate market.

Price bubbles emerge in the market segments or on the assets promising the highest return on investment of all the opportunities on offer. However, the anticipated rate of return does not stand in isolation. For the purpose of idealization it can be assumed that the argument for investing in specific assets will be a positive difference between the return on capital and the cost of that capital.

The origin of price bubbles is related to an emerging disparity between the price and the fundamental value, or a lack of correspondence between the transactional prices and the equilibrium price. Thus they may result either from inflated prices, which must be related to excessive liquidity of a market sector ("normal" price bubbles), or from deflated prices and a lack of liquidity in a specific market sector (reverse bubbles).

Our understanding of a price bubble morphology requires prior understanding of the synergy of individual activities. The descriptive model of explaining the price bubble phenomenon is not essentially useful since it does not reach the core of this problem. This results basically from the nomological diversification of price bubbles. Therefore it seems necessary to explain the price bubble diversity through identifying the causative and regulatory factors of their appearance and rapid disappearance as well as the nature of their inter-relationships. Construction of the idealized models of a price bubble formation and burst requires discarding some basic assumptions of the orthodox economic theory, namely the paradigm of hard financing, the absolute rationality of 
decision makers and the possibility of acting with an absolute certainty arising from the access to complete information and the lack of any risk.

Even if all price bubbles look alike at first sight, they are not identical. The sources of their diversification include: the type and weight of the causes of their appearance, the differences between their causative and functional determinants and the market feedbacks. Any interpretation of the nomological diversification of price bubbles (in the sense of their categorisation) requires looking at the system pragmatics and the market in which they emerge. Thus the designations of economic systems and the specifics of markets constitute both the economic and the institutional environment of their origin. They also constitute the necessary context for their understanding and interpretation, as price bubbles rise and collapse within specific functional structures of an economic system. The conceptualisation and utilisation of those determinants for the understanding of price bubbles in relation to the functional structure of economic system and the type of market where they emerge is therefore necessary for understanding the nature of heterogeneity of price bubbles and, consequently, of their typological and nomological diversity.

\section{Notes}

1 Boudon (2008), p. 266.

2 Philip Carret defines speculation as the purchase or sale of securities or commodities in expectation of profiting by fluctuations in their prices. Pure speculation involves buying and selling in the same market without rendering any service in the way of distribution, storage or transportation; cf. Carret (1998), p. 4.

3 Gordon Gekko, the hero of Wall Street film (1987) where the role was played by Michael Douglas, claims in one scene that "Greed, for lack of a better word, is good. Greed is right. Greed works. Greed clarifies, cuts through, and captures, the essence of the evolutionary spirit. Greed, in all of its forms: greed for life, for money, for love, knowledge, has marked the upward surge of mankind".

4 One of the new, fundamental paradigms of the IFRS is fair value accounting. Fair value, as opposed to the acquisition cost, reflects the future economic benefits that the asset owner will earn from its ownership. Upon applying the fair value of an asset at the closing date, the business anticipates and discloses future benefits with some natural uncertainty. In accordance with the definition as provided by the national Accounting Law and the IFRS, "fair value is the amount for which an asset could be exchanged, a liability settled, or an equity instrument granted could be exchanged between knowledgeable, willing parties in an arm's length transaction". The definition implies that the transaction is hypothetical, and possible as on the valuation date. The 'knowledgeable' description suggests that each party to the transaction has sufficient knowledge of the transaction object, its price determinants and market situation on the valuation date. Additionally, the phrase 'an arm's length transaction' introduces the prerequisite of the parties acting as independent contractors, i.e. the lack of any relationship that could make them negotiate a price different from the market price (after: Helin (2008.

5 Żelazowski (2007), pp. 139-140.

${ }^{6}$ In practice, the rates of return refer to specific time spans. Therefore we deal with the annual, quarterly, monthly, weekly or daily rates of return on investment.

${ }^{7}$ LeRoy, Gilles (1992), p. 74.

${ }^{8}$ Malkiel (2003), pp. 61-67.

${ }^{9}$ Hagstrom (2001), p. 64. 


\footnotetext{
10 Andressen (2002), p. 142.

${ }^{11}$ Kaczmarek (2007).

12 Herring \& Wachter (2005), p. 221.

${ }^{13}$ Green \& Wachter (2007), p. 9.
}

\section{References}

Allen, F., \& Gale, D. (2000). Bubbles and Crises. Economic Journal, 110.

Andressen, C. (2002). Krótka historia Japonii. Od Samuraja do Sony [Polish edition of A Short History of Japan: From Samurai to Sony]. Warsaw: Wydawnictwo Akademickie DIALOG.

Boudon, R. (2008). Efekt odwrócenia. Niezamierzone skutki działań społecznych [Polish edition of Effets pervers et ordre social]. Warsaw: Oficyna Naukowa.

Brilman, J. (2002). Nowoczesne koncepcje i metody zarzadzania [Polish edition of Les meilleures pratiques de management: au coeur de la performance].Warsaw: PWE.

Cartwright, N. (1989). Nature's Capacities and Their Measurement. Oxford: Clarendon Press.

Carret (1998). Nauka spekulacji [Polish edition of The Art of Speculation]. Warsaw: K.E. Liber.

Case, R.K., \& Shiller, E.J. (2003). Is There a Bubble in the Housing Market? Brookings Papers on Economic Activity, 2.

Green, R.K. \& Wachter, S.M. (August 1, 2007). The Housing Finance Revolution. University of Pennsylvania, Inst. for Law \& Economic Research Paper No. 09-37. Available at SSRN: http://dx.doi.org/10.2139/ssrn.1491688.

Greenspan, A. (2008). Era zawirowań. Krok w nowy wiek [Polish edition of The Age of Turbulence: Adventures in a New World]. Warsaw: Warszawskie Wydawnictwo Literackie MUZA SA.

Hagstrom, R.G. (1994). Na sposób Warrena Buffeta - Strategie największego na świecie inwestora kapitałowego [Polish edition of The Warren Buffet Way]. Warsaw: WNT.

Hagstrom, R.G. (2001). Portfel Warrena Buffeta. Potega strategii inwestowania skoncentrowanego [Polish edition of The Warren Buffett Portfolio]. Warsaw: WNT.

Helin, A. (2008). Wycena według wartości godziwej - przyczyna kryzysu finansowego czy też jego miernik? [Fair Value Pricing: Cause or Measure of the Financial Crisis?]. BDO, Podatki i rachunkowość, 11 (13), November. 
Herring, R., \& Wachter, S. (2005). Bubbles in Real Estate Markets. In: W.C. Hunter, G.G. Kaufman \& M. Pomerleano (Eds.), Asset price bubbles. The implication for monetary, regulatory and international policies. London: MIT Press.

Kaczmarek, T.T. (2007). Globalistyka. Przyszłość globalnej gospodarki [Globalisation. The Future of Global Economy]. Warsaw: DIFIN.

Kalicki, K., \& Krześniak, A. (2010). Polityka pieniężna w strefie EURO i USA a ceny aktywów w świetle doświadczeń z kryzysu [Asset Prices and Monetary Policies in the US and the Eurozone: Lessons from the Crisis]. In: G.W. Kołodko (Ed.), Globalizacja, kryzys i co dalej? Warsaw: Poltext.

Kindleberger, Ch. (1992). Bubbles. In: The New Palgrave Dictionary of Money and Finance. London: Macmillan.

LeRoy, S.F., \& Gilles, Ch. (1992). Asset price bubbles. In: The New Palgrave Dictionary of Money and Finance. London: Macmillan.

Levine, D.P. (2000). The Attachment of Greed to Self-Interest. Psychoanalytic Studies, 2 (2), June.

Malkiel, B.G. (2003). Błądzac po Wall Street. Dlaczego nie można wygrać z rynkiem? [Polish edition of A Random Walk Down Wall Street], Warsaw: WIG-Press.

Shiller, R.J. (2005). Diverse views on asset bubbles. In: W.C. Hunter, G.G. Kaufman \& M. Pomerleano (Eds.), Asset price bubbles. The implication for monetary, regulatory and international policies. London: MIT Press.

Sławiński, A. (2006). Rynki finansowe [Financial Markets]. Warsaw: PTE.

Żelazowski, K. (2007). Zjawisko bańki cenowej w kontekście zmian na polskim rynku mieszkaniowym [Price Bubbles in the Context of Fluctuations in the Polish Housing Market]. Studia i Materiaty Towarzystwa Naukowego Nieruchomości, 15 (1-2). Olsztyn: Towarzystwo Naukowe Nieruchomości. 